\title{
Operationalized Psychodynamic Diagnosis (OPD-2) of an Adolescent in Conflict With the Law
}

\author{
Luciane Maria Both \\ Federal University of Rio Grande do \\ Sul (UFRGS), Rio Grande do Sul, \\ Brazil
}

\author{
Taís Cristina Favaretto \\ Universidade do Vale do Rio dos \\ Sinos (UNISINOS), Rio Grande do \\ Sul, Brazil
}

\author{
Sílvia Pereira da Cruz Benetti \\ Universidady of Vale do Rio dos \\ Sinos (UNISINOS), Rio Grande do \\ Sul, Brazil
}

There is a scientific effort to construct instruments that evaluate the patient's psychodynamic functioning and improve clinical/academic communication. Therefore, the operationalized psychodynamic diagnosis (OPD-2) was created to perform a multiaxial diagnosis based on five axes: experience of illness and prerequisites for treatment (Axis I); interpersonal relationships (Axis II); conflict (Axis III); structure (Axis IV); mental and psychosomatic disorders (Axis V).This study aimed to identify the psychodynamic characteristics from an audio recorded treatment session with an 18-year-old adolescent in conflict with the law, serving detention without the possibility of external activities. In Axis I, median severity of the problem was observed, but with a level of suffering almost absent. In Axis II, he experiences others as controllers, which disqualify and neglect him, thus, he seeks to keep to himself by maintaining distant, to the point where there is uncontrolled impulses, aggression, and exposure to risk. In Axis III, there was a predominance of conflicts: need to for care versus self-sufficiency and self-esteem conflict. The Axis IV showed a median level structure with internalization of negative models and difficulty in mentalization. The Axis V showed that the patient has a diagnosis of International Statistical Classification of Diseasesand Related Health Problems (ICD), which refers to Conduct Disorders, being characterized by persistent patterns (six months or more) of anti-social, aggressive or confrontational conduct. The OPD-2 has been shown to be a useful tool for identifying the psychic characteristics of adolescents in conflict with the law and for therapeutic planning.

Keywords: operationalized psychodynamic diagnosis (OPD-2), adolescent in conflict with the law, psychodynamic evaluation, mentalization.

\section{Introduction}

Diagnostic research in psychoanalysis has stood out due to the deficiencies in the operationalization of a comprehensive psychodynamic diagnosis in detriment to the descriptive diagnosis (Cierpka et al., 2010). Hence, an instrument called operationalized psychodynamic diagnosis was created, which integrates the psychodynamic dimension to the common descriptive symptomatology of the diagnostic manuals through rigorous and reliable evaluation criteria that allows a standardization and an approximation of the investigation to practice (OPD Task Force, 2008).

Luciane Maria Both, doctor student in Federal University of Rio Grande do Sul (UFRGS).

Taís Cristina Favaretto, master in Clinical Psychology in Universidade do Vale do Rio dos Sinos (UNISINOS).

Sílvia Pereira da Cruz Benetti, professor at the University of Vale do Rio dos Sinos (UNISINOS). 
Most of these studies are based on the adult age group, with reduced research directed to analysis in psychotherapy in childhood and adolescence (Midgley, 2008; Tonge, Pullen, Hughes, \& Beaufoy, 2009). It is estimated that between $10 \%$ and $25 \%$ of children and adolescents present some clinical impairment attributed to mental disorders at some point in life (Merikangas et al., 2010). According to Thiengo, Cavalcante, and Lovisi (2014), mental disorders with higher incidence in childhood and adolescence are depression, anxiety disorder, attention deficit hyperactivity disorder, substance use disorder, and conduct disorder. In the clinic with adolescents, cases with risk behaviors (Chanen \& McCutcheon, 2013), such as violence against others, acts and criminal acts are frequently witnessed (Shiner \& Allen, 2013).

In Brazil, in more serious cases such behavior may be associated with antisocial conducts, and can be condemned, socially, and legally, with the restrictions of freedom as an outcome. Adolescents aged 12 to under 21 were considered responsible, who committed an offense and were sentenced by a competent authority, they may receive as a socio-educational measures the obligation to repair harm, providing community service, probation, part-time confinement and confinement in specific establishment (Presidência da República, Casa Civil, \& Subchefia para Assuntos Jurídicos, Brazil-Lei 8069, 1990). Brazilian data from the Levantamento Anual dos/as Adolescentes em Cumprimento de Medida Socioeducativa (Annual Survey of Adolescents under Socio-educational Measures) published by the Secretariat of Human Rights indicate that 20,532 adolescents were in confinement, temporary confinement, and part-time confinement in 2012 . Of these, $95 \%$ are male (Secretaria de Direitos Humanos da Presidência da República, 2013).

Nevertheless, it is considered that the problem of the adolescent in conflict with the law, became, in Brazil, a public health issue, due to the seriousness of the involvement and the early manifestation of the aggressive and even antisocial behaviors presented.

Such youth have the characteristic of low level of reflective function, as demonstrated in the literature (Bateman \& Fonagy, 2013). Mentalization or reflexive function is defined as the subject's ability to recognize one's own thoughts, feelings, beliefs, and desires and to give meaning to the other's behavior, allowing prediction and interpretation of intentions and feelings (Bateman \& Fonagy, 2010; Asen \& Fonagy, 2012; Fonagy \& Allison, 2012). In this way, the use of Mentalization-Based Treatment, created by Peter Fonagy was chosen (Bateman \& Fonagy, 2010, 2013; Eizirik \& Fonagy, 2009; Fonagy, Gabbard, \& Clarkin, 2013).

However, there are gaps in scientific evidence regarding treatment planning for this population, since evaluation and diagnosis in adolescence is still a controversial issue, since the subjects are in development and the trajectories experienced.Therefore, the OPD is an instrument that allows from the multiaxial evaluation, the treatment focus and planning, in which it is possible to work out the specific and fundamental issues relevant to each individual patient, according to their abilities and characteristics.

In summary, there is a need for deeper understanding in regards to adolescence in relation to their difficulties. This research focuses on the operationalized psychodynamic evaluation, more specifically, it turns to the multiaxial diagnosis that comprises five axes, of which four of them are psychodynamic and the last one is descriptive: (I) experience of the illness and prerequisites for treatment; (II) interpersonal relationships; (III) psychic conflict; (IV) psychic structure; (V) traditional nosological diagnosis (OPD Task Force, 2008). Correspondingly, through a systematized case study, we turn to the identification of the level of reflexive function. In the present case, it is emphasized that the treatment followed the prerogatives of Mentalization-Based Treatment. Thus, this research sought to identify the psychodynamic characteristics from 
an audio recorded treatment session of a teenager with 18 years of age in conflict with the law, under a Socio-educational Measures in a closed environment.

\section{Method}

\section{Participant}

The participant John was 18 years old and was under Social and Educational Measures, in a closed environment, in a correctional institution in Rio Grande do Sul/Brazil, due to the offense of attempted robbery resulting in murder. Before his confinement, he lived with his mother and older brother. He also had a younger brother who was serving the Brazilian army. He studied in the first year of high school and had failed twice. When he was about seven years old, his father separated from his mom and left his kids in the state of Rio Grande do Sul and went to live in Mato Grosso with his new girlfriend. John says that he felt abandoned, without understanding the reasons for his father leaving. He says that he always had the feeling of not belonging to his family, of being rejected by his father since he had a physical appearance different from him and his brothers. He idealized a new meeting with his father that happened when he was 12 years old.When reunited, he was ignored, bringing about the perception of abandonment and increase of anger and resentment for this event. As a teenager, he could not keep up with work activities, getting involved with people participating in illicit acts. He points out that he had only one true friend, with whom he divided all his choices and thoughts. He tried to stay away from others, including his brothers, with whom he was often compared to, a point that made him angry. His mother had no control over his decisions, unable to set limits, showing herself to be fragile.

The offence occurred when collecting a third party debt. John struck the victim in the neck with a machete. He reveals that he had sensations of adrenaline and joy for having completed what had been requested, and at the same time, fear of being caught. He was free for about eight months after the offense. Initially, when he was confined, he wondered how he was caught, since he had a story that would cover him. In the institution, he receives occasional visits from his mother.

\section{Procedure}

This is the analysis of a systematic case of an 18-year-old teenager. The therapist is a 34-year-old psychologist and has 10 years of clinical experience. She has a background in Psychoanalytic Psychotherapy Counseling. The treatment consolidated into the Fonagy Mentalization Based Treatment. The understanding of the case occurred early in treatment, under the analysis of the instrument operationalized psychodynamic diagnosis (OPD-2), a session of 45-minute period, with regards to psychotherapeutic treatment based on mentalization. The manual is based on the presuppositions of attachment and object relations theory (OPD Task Force, 2008). It has been valid in Brazil since 2012 with adequate psychometric properties (Vicente et al., 2012; Krieger, 2013).

The interview was recorded, with authorization from the Fundação de Atendimento Socioeducativo (Socio-Educational Treatment Foundation), by the adolescent's legal guardian and his assent. Subsequently, the interview was transcribed and evaluated by a judge trained in the OPD, who coded the sessions according to the manual.After the coding, the psychodynamic understanding was returned to the therapist for the confirmation of data, since the evaluating judge did not have contact with the adolescent (OPD Task Force, 2008).

\section{Instrument}

The Psychodynamic Operational Diagnosis (OPD)(OPD Task Force, 2008) is an instrument created by psychoanalysts, psychiatrists, and specialists in psychosomatic medicine in Germany, with the purpose of 
broadening the classification of psychic disorders of International Statistical Classification of Diseases and Related Health Problems 10th revision (ICD-10) in the description of symptoms introducing psychodynamic dimensions. The Brazilian version of the instrument was used in this study (Vicente et al., 2012). Table 1 presents a detailed description of the Axes, Dimensions evaluated and Indicators.

Table 1

Description of the OPD-2 Axes

\begin{tabular}{|c|c|c|}
\hline Axes & Dimension & Indicator \\
\hline \multirow{3}{*}{$\begin{array}{l}\text { Axis I-Illness experience and } \\
\text { prerequisites for treatment }\end{array}$} & Objective assessment of illness/problem & $\begin{array}{l}\text { 1.Current severity of illness/ problem } \\
\text { 2. Period of illness/problem }\end{array}$ \\
\hline & $\begin{array}{l}\text { Patient experience, presentation and } \\
\text { conceptualization of the illness }\end{array}$ & $\begin{array}{l}\text { 3. Experience and presentation of the disease } \\
\text { 4. Conceptualization of the illness by the patient } \\
\text { 5. Conceptualization of change by the patient }\end{array}$ \\
\hline & Resources and resistance to change & $\begin{array}{l}\text { 6. Resources for change (last six months) } \\
\text { 7. Resistances to change }\end{array}$ \\
\hline \multirow{2}{*}{ Axis II-Interpersonal relations } & Perspective A: Patient experience & $\begin{array}{l}\text { The patient perceives himself as ... } \\
\text { The patient perceives others as ... }\end{array}$ \\
\hline & $\begin{array}{l}\text { Perspective B: The perception of others } \\
\text { (including of the researcher) }\end{array}$ & $\begin{array}{l}\text { Others perceive the patient as ... } \\
\text { Others perceive themselves as ... }\end{array}$ \\
\hline \multirow{10}{*}{ Axis III-Conflict } & \multirow{5}{*}{ Repetitive dysfunctional conflicts } & $\begin{array}{l}\text { 1. Individuation versus dependency } \\
\text { 2. Submission versus control }\end{array}$ \\
\hline & & $\begin{array}{l}\text { 3. The need for care versus self-sufficiency } \\
\text { 4. Conflict of self-esteem }\end{array}$ \\
\hline & & 5. Conflict of guilt \\
\hline & & 6. Oedipal conflict \\
\hline & & 7. Identity conflict \\
\hline & \multirow{5}{*}{ How the main conflict is handled } & Predominantly active \\
\hline & & Mixed more active \\
\hline & & Mixed more passive \\
\hline & & Predominantly passive \\
\hline & & Non-classifiable \\
\hline \multirow{8}{*}{ Axis IV-Structure } & \multirow{2}{*}{ Cognitive abilities } & 1a. Self perception \\
\hline & & 1b. Perception of the object \\
\hline & \multirow{2}{*}{ Regulation } & 2a. Self-regulation \\
\hline & & $2 b$. Regulation of the object relation \\
\hline & \multirow{2}{*}{ Emotional communication } & 3a. Internal communication \\
\hline & & 3b. Communication with the outside world \\
\hline & \multirow{2}{*}{ Attachment } & 4a. Attachment capacity: Internal objects \\
\hline & & 4b. Attachment capacity: External objects \\
\hline \multirow{2}{*}{$\begin{array}{l}\text { Axis } \mathrm{V}-\text { Mental and } \\
\text { psychosomatic disorders }\end{array}$} & Mental disorders & Main/additional diagnostics \\
\hline & Personality disorders & Main/additional diagnostics \\
\hline
\end{tabular}

Note. Vicente et al. (2012).

\section{Results}

Axis I evaluates the patient's experience of suffering, the causes that he attributes to his problems and the support network who the patient can count on (OPD Task Force, 2008). The evaluated patient did not demonstrate experience of psychological, physical or social problems; but there is resistance in expressing 
himself, presenting internal psychic limitations: lack of control of impulses, difficulty in trusting others, and limited reflexive capacity. The causes of his problems, such as the reason for the confinement, are attributed by him to work problems, without considering it as a risk for himself and for the others to be involved with this type of illicit activity.

Regarding the external support network, he receives occasional visits from his mother in the correctional institution. He says that they don't have a good relationship, always fighting. Therefore, he cannot perceive her as a person who can help him handle his problems and organize himself. In relation to his girlfriend, perceives her distanced, not giving him support.

Axis II of the OPD is the relational axis (Interpersonal Relations) where the relational dynamics are formed with the patient, having origin in intrapsychic and relationship conflicts. It considers both the patient's perspective, in the sense of how he describes his relational experiences and his own behavior and the perspective of the others, including the therapist, how they experience and perceive the relationship with the patient (OPD Task Force, 2008; Krieger, 2013).

For this young man, others seek to dominate and control him, demanding that he perform tasks, as in the case of drug dealers. He still feels disqualified, as they try to embarrass him in regards to his attitudes, or fail to give him care, acting carelessly, and abandoning him. As well as, at different moments, the patient acts impulsively, having low self-care and ending up exposing himself to risk situations: attacking others, causing them harm; acts in a way to ignore them, since he feels that he is being mocked. He repeats this act until he can control himself. Consequently, he establishes relationships where others protect themselves from his possible attacks, not attaching himself, thus avoiding aggressions and withdrawing-abandon him-by reducing contact and establishment of affective bond. Thus, a cycle is established where the patient addresses little to others and ignores them, as well as attacks them and exposes himself to danger, without analysis.

The conflict-Axis III-is considered the central aspect in the patient's psychodynamic understanding (OPD Task Force, 2008). In this case, the central conflict of the patient refers to the active mode need for care versus self-sufficiency. The patient demonstrates conditions of establishing relationships and attachment bonds; however, he is characterized by establishing relationships in which he seeks to be self-sufficient. He describes family bonds as positive as a defense against the appearance of painful resources. He worries about his mother and with the others, how to take care for them, as an unconscious way of being cared for. He also presents underlying depressive feelings that are defensively rejected. It can still be said that his effort to achieve independence can lead him to an early separation from his family of origin. His quest for self-sufficiency runs through the efforts to build independence through professional life.

He demonstrates as a secondary conflict, active mode self-esteem conflict, which indicates a lack of recognition of his own worth. Although he says that others fear him after aggressive behavior, such as at school; and his relatives "handed him over" the responsibility to family properties, a large amount of land, an attempt to reinforce his capacity predominates, to show security in positive images-narcissistic-of himself. Property (land) serve as representative attributes of self-worth, but often these attributes are more present in patient's desires and fantasies than in reality. Also, he tries to reverse his perception of the devaluation and abandonment of his girlfriend, seeking to increase his self-esteem when he states that he does not know what he was doing with her and does not need it.

Regarding the other conflicts, it is still possible to confirm that there are difficulties of self-control and a search for control over others from aggressive attitudes. There is no sense of guilt, even though he recognizes 
that he is deprived of his freedom by his actions. A conflict about nationality (Rio Grande do Sul versus Mato Grosso) is perceived, in which he does not identify with the place in which he lives, not feeling he belongs. He is concerned about his professional identity, since his work attempts were not positive, seeking greater independence, freedom and a job that he appreciates.

The structural axis-Axis IV-evaluates the level of integration of the patient's abilities or limitations in the regulation of mental functions capacity of establishing homeostasis, regulation of their internal experience and the management of stress and overload, allowing elaboration and adaptation. The emotional structure is the result of a process of growth and the development of internal representations of the world (OPD Task Force, 2008). In general, the patient demonstrated a median level of structure. In his functions, we observe:

1. Self-perception: Patient concentrates on concrete (said and done) with limited capacity for self-reflexive perception, although he began to notice his attitudes of "improvement" in the confinement; perceives affections in a limited way; has gaps in self-image depending on the situation and mood;

2. Perception of the object: Affections, impulses, and thoughts regarding self and the object are insecure. He attributes to others unbearable affections (projection), does not perceive them in their complexity, but rather experiences them according to his own desires, being difficult to perceive them realistically;

3. Self-regulation: Conflicts are inhibited by overregulation or may occasionally erupt. Negative affections can over power him and become unbearable, triggering aggressive and destructive behaviors. Just as, self-esteem changes in the presence of bullying and is expressed inpride or withdrawal;

4. Regulation of the object: Regulation of his own interests and of others are not fully harmonized. The negative reactions of others are anticipated in a limited way (mentalization). The impulses can be partially elaborated and there is difficulty of intrapsychic handling that affects the interpersonal relations;

5. Internal communication: Affections are experienced in a limited way (mentalization) and negative affections emerge uncontrolled. He uses fantasy and dreams to expand the reality. There is insecurity about body image;

6. Communication with the external world: Contact and relations are restricted. Limitation in understanding the feelings of others, of putting yourself in their place (empathy) and in relation to their own desires and fears. There is lack of contact and retentive behavior that reduced ability to differentiate affections and communicate them (mentalization);

7. Ability of attachment to internal objects: There is difficulty in developing stable internal images of important people, in which he does not rely on positive internal objects and cannot reassure or protect himself; anguish of losing the object;

9. The capacity of attachment to external objects: he relates in a brief and tottering way, whose affective meaning of the other can be exaggerated. Demonstrates difficulty in asking and finding help. And he avoids farewells, preferring him to "abandon", because he fears losing the object.

And finally, Axis V comprises the diagnosis according to the Diagnostic and Statistical Manual of Mental Disorders (DSM) or International Statistical Classification of Diseasesand Related Health Problems (ICD) (OPD Task Force, 2008). The patient has a diagnosis of ICD-10, F 91, that refers to Conduct Disorders, being characterized by persistent patterns (six months or more) of anti-social, aggressive or confrontational conduct (Organização Mundial da Saúde, 1997). At different times, his behavior violates social expectations since he excessively manifests his aggressiveness and tyranny; his behavior destroys the property of others; and his behavior has conduct like robberies, lies, and frequent and serious disobedience. 


\section{Discussion}

The objective of the present study was to evaluate the applicability of OPD-2 in the analysis of a session of psychoanalytic psychotherapy based on mentalization and the elaboration of the participant's multiaxial diagnosis. The case described refers to an 18-year-old male, under Socio-educational Measures in confinement in a closed environment. It is observed that the results corroborate with the literature, regarding the characteristics of adolescents in conflict with the law in several aspects.

When observing the laws governing the care of adolescents in conflict with the law, there is an evolution regarding the concern and need to respect the peculiar condition of a person in development. However, in addition to the factors related to the increasing involvement in offending acts, it is disturbing for clinicians and researchers how their psychic records occur, showing the way they deal with their feelings, seeing those around them and also relate. Thus OPD-2 emerges as a proposal for a broad and comprehensive understanding, allowing an approximation of research to practice, where the processes and results can be defined and operationalized in different change variables, symptoms, relational patterns, conflicts, and structure, effectiveness and the therapeutic relationship (Paulo \& Pires, 2013).

Regarding the experiences of psychological factors (Axis I), the patient does not recognize feelings of suffering, only shows limitations in impulse control, distrust and low mentalization. The adolescent under study corroborates with the research that indicates that adolescents in conflict with the law present low mentality, causing difficulties in understanding their feelings and of the other, leading to emotional dysregulation and distortions in the perception of self and of the other (Quiroga \& Cryan, 2012; Fonagy et al., 2013). These characteristics are pointed out as having an impact on the attachment capacity and are therefore negative in therapeutic efficacy (Schneider, Mendler, Heuft, \& Burgmer, 2008).

On Interpersonal Relations (Axis II), the OPD-2 analyzes from two perspectives, A and B, which translate relational experiences from the perspective of the patient and from the perspective of the other (Krieger, 2013). In the present study, the therapist's feelings towards the patient are not evident. However, it is pointed out that the feelings of distrust, difficulties of approach, and attachment and attempts to control others, are linked to the fear of disqualification, abandonment and rejection, experienced by distant family affection. Furthermore, a mapping of the situation of confinement of adolescents in Brazil, demonstrated and alerted that the practice of offenses usually relates to the quality of the attachment and the need for the parental presence extends to subjective aspects involving support, protection, and limits (Silva \& Gueresi, 2003). Thus, family coexistence can be considered a protective factor for the act of offenses (Paiva \& Ronzani, 2009; Zappe \& Dias, 2012).

Thus, the experience of possible traumatic experiences in childhood can produce dysfunctionalities in the perception of oneself and other (Bateman \& Fonagy, 2010; Zappe \& Dias, 2012), making it difficult to acquire the capacity to mentalize. In this sense, the subject has a greater risk of using, in a predominating way, an automatic or instinctive mode of reflection to detect threats in the environment, rather than a reflexive mode (Brent, 2015).

Patient conflict, need for care versus self-sufficiency, and conflict of self-esteem, reinforce the observation of his unconscious desire to be cared for and the search for the reversal of the sense of devaluation by the development of independence. Such experiences produce difficulties in trusting others, making his bonds end up being superficial and not long lasting, being alone, not needing anyone-girlfriend or mother. 
The other conflicts demonstrate his problem in the control of impulses and the desire to dominate others, sometimes, acting in an uncontrolled and aggressive way. Gacono, Evans, Nancy, and Viglione (2016) supports the results by finding maladaptive and even unusual behaviors in forensic assessments, pointing out low resources of the subjects that present conflict with the law to deal with the demands of daily life. Still other authors report that the lack of control and aggressive behavior are directly associated with low scores in mentalization, are also predictives of mental illness and symptoms of psychopathy (Liotti \& Gilbert, 2010; Olin \& Keatinge, 1998; Rosa Júnior, 2006; Sharp et al., 2013). Aggressiveness, intolerance to frustration, and poor impulse control may also be related to antisocial aspects, even when evaluated in childhood or adolescence (Farrington, 2005; Veirmeiren, 2003).

In regards to Axis IV, structural axis, it was observed that the patient's structure is at the median level. He presents a lack of integration of the concept of self, which is understood by Preti et al., (2015) as a fragmented image of themselves causing feelings of intense emptiness, internal insecurity, poor emotional regulation, and low self-esteem. According to Schmeck, Schlüter-Müller, Foelsch, and Doering (2013), it can be said, constitution of the self refers to the interpersonal functioning that underlies the notion of empathy and intimacy, the ability to recognize the expectations of others and to establish close relationships and make coherent decisions. Such characteristics tend to have problems in relation to following rules, which hampers planning or perspective of the future (Fonagy \& Allison, 2012).

In summary, the conflicting patient presented several specific dysfunctionalities of Conduct Disorder, such as traumatic experiences, emotional instability, lack of integration of the self, difficulties of mentalization, and in interpersonal relationships, among others. In this sense, psychotherapy based on mentalization uses specific techniques to promote the improvement of the psychological functioning of the patient; whose multiaxial diagnostic evaluation helps in the planning and therapeutic focuses directed to the difficulties in patients.

Although the involvement of young people in illicit acts is not a recent problem, it is necessary to deal more effectively, both from the perspective of prevention and intervention, in view of the increase in the incidence of trajectories that lead to the delinquent/violent act. In this sense, the issue is considered a public health problem due to the early manifestation of aggressive and even antisocial behaviors.

\section{Conclusion}

OPD-2 has been shown to be a useful tool for identifying the psychic characteristics of adolescents in conflict with the law and for future therapeutic planning. It was possible to develop a dimensional understanding about the adolescent more clearly, being consistent to the descriptive diagnosis, ICD F 91, and Conduct Disorders. However, it is necessary to expand the sample and the attention of adolescents in different contexts and different personal characteristics to consolidate the results.

\section{References}

Asen, E., \& Fonagy, P. (2012). Mentalization-based therapeutic interventions for families. Journal of Family Therapy, 34, 347-370. doi: 10.1111/j.1467-6427.2011.00552.x

Bateman, A., \& Fonagy, P. (2010). Mentalization based treatment for borderline personality disorder: Special article. World Psychiatry, 9, 11-15. doi: 10.1002/j.2051-5545.2010.tb00255.x

Bateman, A., \& Fonagy, P. (2013). Mentalization-based treatment. Journal Psychoanalytic Inquiry, 33(6), 595-613. doi: $10.1080 / 07351690.2013 .835170$

Brent, B. (2015). A mentalization-based approach to the development of the therapeutic alliance in the treatment of schizophrenia. Journal of Clinical Psychology, 71(2), 146-156. doi: 10.1002/jclp.22150 
Chanen, A. M., \& McCutcheon, L. (2013). Prevention and early intervention for borderline personality disorder: Current status and recent evidence. The British Journal of Psychiatry, 202(54), 24-29. doi: 10.1192/bjp.bp.112.119180

Cierpka, M., Stasch, M., Grande, T., Schauenburg, H., De la Parra, G., Rost, R., y miembros del Grupo de Trabajo OPD. (2010). La evaluación de primeras entrevistas psicoterapêuticas mediante el sistema diagnóstico psicodinâmico operacionalizado (OPD-2)[The evaluation of first psychotherapeutic interviews through the psychodynamic diagnostic system operationalized (OPD-2)]. Clínica e Investigación Relacional: Revista Electrónica de Psicoterapia [Clinic and Relational Research: Electronic Journal of Psychotherapy], 4(1), 221-235.

Eizirik, M., \& Fonagy, P. (2009). Mentalization-based treatment for patients with borderline personality disorder: an overview. Rev Bras Psiquiatr. 31(1), 72-85. doi: 10.1590/S1516-44462009000100016

Farrington, D. P. (2005). Childhood origins of antisocial behavior. Clinical psychology \& psychotherapy, 12(3), 177-190. doi: $10.1002 /$ cpp.448

Fonagy, P., \& Allison, E. (2012). What is mentalization? The concept and its foundation in developmental research. In N. Midgley, \& I. Vrouva (Eds.), Minding the child (pp. 11-34). London and New York: Routledge.

Fonagy, P., Gabbard, G. O., \& Clarkin, J. F. (2013). Psicoterapia psicodinâmica para transtornos da personalidade: Um manual clínico [Psychodynamic psychotherapy for personality disorders: A clinical manual]. Porto Alegre: Artmed.

Gacono, C. B., Evans, F. B., Nancy, K. B., \& Viglione, D. J. (2016). The Handbook of Forensic Rorschach Assessment. Retrieved from https://www.routledgehandbooks.com/doi/10.4324/9780203810071.ch3

Krieger, D.V. (2013). Operationalized psychodynamic diagnosis 2: Apresentação da versão brasileira e estudos preliminares de validade e confiabilidade [Operationalized psychodynamic diagnosis 2: Presentation of the Brazilian version and preliminary studies of validity and reliability] (Master's thesis, Universidade Federal do Rio Grande do Sul, Porto Alegre, BR-RS). Retrieved from http://hdl.handle.net/10183/143052

Liotti, G., \& Gilbert, P. (2010). Mentalizing, motivation, and social mentalities: Theoretical considerations and implications for psychotherapy. Psychology and Psychotherapy: Theory, 84(1), 9-25. doi: 10.1348/147608310X520094

Merikangas, K. R., He, J. P., Brody, D., Fisher, P. W., Bourdon, K. \& Koretz, D. S. (2010). Prevalence and treatment of mental disorders among US children in the 2001-2004 NHAES. Pediatrics, 125(1), 75-81. doi: 10.1542/peds.2008-2598

Midgley, N. (2008). Overview of the research on individual child and adolescent psychodynamic psychotherapy. In G. Carlberg, P. Eresund, \& S. B. Boëthius (Eds.), Child and adolescent psychotherapy research (pp. 11-34). Stockholm: Ericastiftelsen.

Olin, J., \& Keatinge, C. (1998). Rapid psychological assessment. New York, NY: John Wiley.

OPD Task Force. (2008). Operationalized Psychodynamic Diagnosis OPD-2: Manual of Diagnosis and Treatment Planning. Retrieved from https://www.amazon.com/Operationalized-Psychodynamic-Diagnosis-OPD-2-Treatment/dp/0889373531

Organização Mundial da Saúde (1997). CID-10 Classificação Estatística Internacional de Doenças e Problemas Relacionados à Saúde [ICD-10 International Statistical Classification of Diseases and Related Health Problems]. São Paulo: Universidade de São Paulo.

Paiva, F. S., \& Ronzani, T. M. (2009). Estilos parentais e consumo de drogas entre adolescentes: Revisão sistemática [Parental styles and drug use among adolescents: Systematic review]. Psicologia em Estudo [Psychology in Study], 14(1), 177-183. doi: $10.1590 / \mathrm{S} 1413-73722009000100021$

Paulo, A. M. R., \& Pires, A. P. (2013). Operacionalização psicodinâmica de diagnóstico (OPD-2) numa psicanálise [Psychodynamic operation of diagnosis (OPD-2) in a psychoanalysis]. Psicologia Clínica [Clinical Psychology], 25(1), 163-178. doi: 10.1590/S0103-56652013000100011

Presidência da República, Casa Civil, \& Subchefia para Assuntos Jurídicos, Brazil-Lei 8069 (1990). Estatuto da criança e do adolescente (ECA)[Statute of the child and adolescent (ECA)]. Retrieved from http://www.planalto.gov.br/ccivil_03/leis/18069.htm

Preti, E., Prunas, A., Panfilis, C., Marchesi, C., Madeddu, F., \& Clarkin, J. (2015). The facets of identity: Personality pathology assessment through the Inventory of Personality Organization. Personality Disorders, 6(2), 129-140. doi: $10.1037 /$ per0000119

Quiroga, S., \& Cryan, G. (2012). Análisisdelproceso em grupos de terapia focalizada para adolescentes violentos: Función reflexiva-RF y modelo de ciclo terapêutico-TCM [Analysis of the process in focused therapy groups for violent adolescents: Reflective function-RF and therapeutic cycle model-TCM]. Retrieved from http://www.aacademica.org/000-052/272.pdf

Rosa Júnior N. C. D. (2006). Adolescência e violência: Direção do tratamento psicanalítico com adolescentes em conflito com a lei [Adolescence and violence: Direction of psychoanalytic treatment with adolescents in conflict with the law] (Master's dissertation, Universidade Federal do Rio Grande do Sul, Porto Alegre, RS, Brasil). 
Schmeck, K., Schlüter-Müller, S., Foelsch, P. A., \& Doering, S. (2013). The role ofidentity in the DSM-5 classification of personality disorders. Childand Adolescent Psychiatry and Mental Health, 7(23), 1-11. doi: 10.1186/1753-2000-7-27

Schneider, G., Mendler, T., Heuft, G., \& Burgmer, M. (2008). Validität der konfliktachse der operationalisierten psychodynamischen diagnostik (OPD-1)-empirische ergebnisseund folgerungenfür die OPD-2 [Validity of the conflict axis of operationalized psychodynamic diagnostic (OPD-1)-empirical results and consequences for OPD-2]. Zeitschriftfür Psychosomatische Medizinund Psychotherapie [Journal of Psychosomatic Medicine and Psychotherapy], 54(1), 46-62. doi: 10.13109/zptm.2008.54.1.46

Secretaria de Direitos Humanos da Presidência da República. (2013). Levantamento Anual dos/as Adolescentes em Cumprimento de Medida Socioeducativa [Annual Survey of Adolescents in Compliance with Socio-educational Measures]. Retrieved from www.sdh.gov.br/assuntos/criancas-e-adolescentes/pdf/levantamento

Sharp, C., Ha, C., Carbone, C., Kim, S., Perry, K., Willians, M., \& Fonagy, P. (2013). Hypermentalizing in adolescente inpatients: Treatment effects and association with borderline traits. Journal of Personality Disorders, 27(1), 3-18. doi: 10.1521/pedi.2013.27.1.3

Shiner, R. L., \& Allen, T. A. (2013). Assessing personality disorder in adolescents: Seven guiding principles. Clinical Psychology: Science and Practice, 20(4). doi: 10.1111/cpsp.12047

Silva, E. R., \& Gueresi, S. (2003). Adolescentes em conflito com a lei: Situação do atendimento institucional no Brasil [Adolescents in conflict with the law: Situation of institutional care in Brazil]. Texto para discussão [Text for discussion], 979, 1-111. Retrieved from https://www.metodista.br/revistas/revistas-ims/index.php/MUD/article/viewFile/4527/4889

Thiengo, D. L., Cavalcante, M. T., \& Lovisi, G. M. (2014). Prevalência de transtornos mentais entre crianças e adolescentes e fatores associados: Uma revisão sistemática [Prevalence of mental disorders among children and adolescents and associated factors: A systematic review]. Jornal Brasileiro de Psiquiatria [Brazilian Journal of Psychiatry], 63(4), 360-372. doi: 10.1590/0047-2085000000046

Tonge, B. J., Pullen, J. M., Hughes, G. C., \& Beaufoy, J. (2009). A naturalistic follow-up Effectiveness of psychoanalytic psychotherapy for adolescents with serious mental illness: 12 month naturalistic follow-up study. Australian and New Zealand Journal of Psychiatry, 43, 467-475.

Veirmeiren, R. (2003). Psycopathology and delinquency in adolescents: A descriptive and developmental perspective. Clinical Psychology Review, 23, 277-318.

Vicente, C. S., Oliveira, R. A., Silva, F., Farrajão, P., Augusto, S., Oliveira, S., ... Krieger, D. (2012). Cross-cultural adaptation of the operationalized psychodynamic diagnosis (OPD-2) in Portugal. Trends in Psychiatry and Psychotherapy, 34(3), 129-138. doi: 10.1590/S2237-60892012000300004

Zappe, J. G., \& Dias A. C. G. (2012). Violência e fragilidades nas relações familiares: Refletindo sobre a situação de adolescentes em conflito com a lei [Violence and fragility in family relations: Reflecting on the situation of adolescents in conflict with the law]. Estudos de Psicologia [Psychology Studies], 17(3), 389-395. doi: 10.1590/S1413-294X2012000300006 